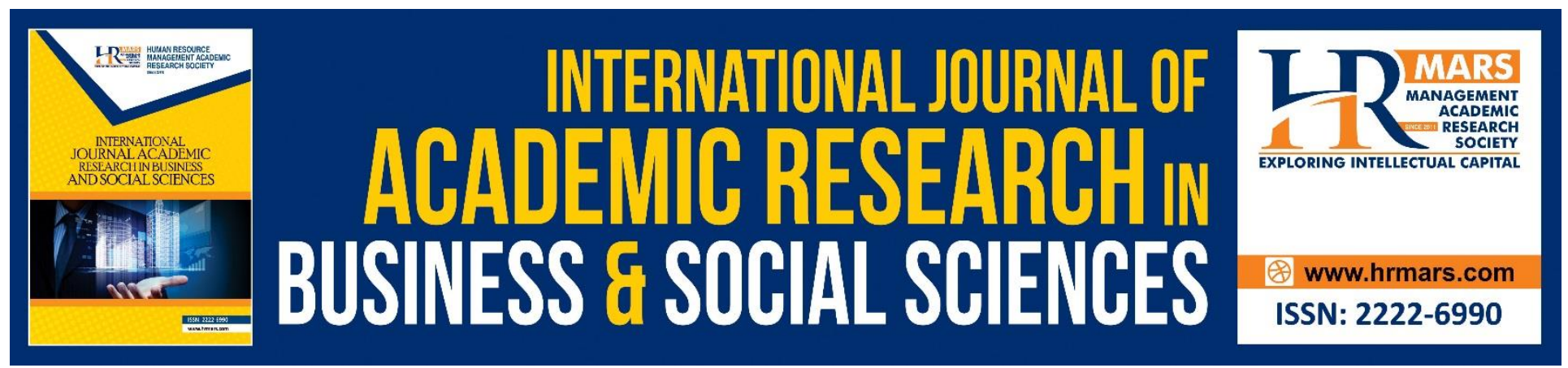

\title{
Cross Country Assessment of Personal Luxury Brands Consumption
}

Mohamad Idham Md Razak, Zailin Zainal Ariffin, Mohd Nor Yahaya, Irzan Ismail

To Link this Article: http://dx.doi.org/10.6007/IJARBSS/v10-i10/8026

DOI:10.6007/IJARBSS/v10-i10/8026

Received: 28 August 2020, Revised: 22 September 2020, Accepted: 07 October 2020

Published Online: 29 October 2020

In-Text Citation: (Razak, Ariffin, Yahaya, \& Ismail, 2020)

To Cite this Article: Razak, M. I. M., Ariffin, Z. Z., Yahaya, M. N., \& Ismail, I. (2020). Cross Country Assessment of Personal Luxury Brands Consumption. International Journal of Academic Research in Business and Social Sciences. 10(10), 966-980.

Copyright: (C) 2020 The Author(s)

Published by Human Resource Management Academic Research Society (www.hrmars.com)

This article is published under the Creative Commons Attribution (CC BY 4.0) license. Anyone may reproduce, distribute, translate and create derivative works of this article (for both commercial and non-commercial purposes), subject to full attribution to the original publication and authors. The full terms of this license may be seen

at: http://creativecommons.org/licences/by/4.0/legalcode

Vol. 10, No. 10, 2020, Pg. 966 - 980

Full Terms \& Conditions of access and use can be found at http://hrmars.com/index.php/pages/detail/publication-ethics 


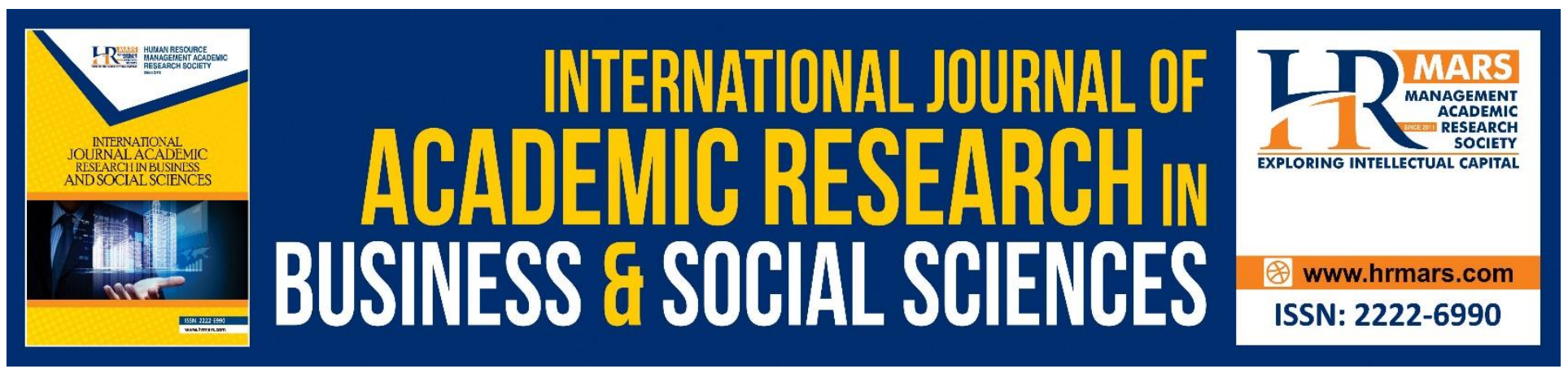

\title{
Cross Country Assessment of Personal Luxury Brands Consumption
}

\author{
Mohamad Idham Md Razak, Zailin Zainal Ariffin, Mohd Nor Yahaya \\ Faculty of Defence Studies \& Management, National Defence University of Malaysia \\ Email: iedham@uitm.edu.my, zailin@upnm.edu.my,mohdnor@upnm.edu.my \\ Irzan Ismail \\ Faculty of Business and Management, Universiti Teknologi MARA Melaka Campus \\ Email: irzan@uitm.edu.my
}

\begin{abstract}
This research aims to investigate the factors affecting the purchasing of personal luxury products by Malaysian and French consumers. In Malaysia and France, a total of 284 functional samples were completed. The data was analyzed using SPSS which also known as (Statistical Package for Social Science). The results of this study are limited to individuals residing in Kuala Lumpur, Malaysia and Paris, France. However, the data collected from these two countries does not represent its entire population. Hence, careful consideration should be used in this research as the results does not represent all of the consumers that centers around Malaysia and Paris. This study indicated that marketers and luxury brand managers should establish effective promotional strategies and programmes in Malaysia and Paris in order to encourage customers to generously invest on personal luxury brand. On the other hand, the imperceptible consumption pattern can also be extended by retailers towards other luxury product groups and service industries.
\end{abstract}

Keywords: Personal Luxury Brands, Cross Country, Consumers, Marketing Strategy, Service Industry

\section{Introduction}

According to Euromonitor International (2016), while Malaysia's ringgit fell to its lowest value and the increasing cost of living in 2016, the purchasing output of different categories of luxury goods still displayed growth in revenue. Chandran (2014) studied that Malaysia 's luxury market is projected to rise steadily in value between the year 2013 and 2018, with inflation of 62 percent over that period. Malaysia 's luxury industry is projected to be worth 1.2 billion US dollars in 2013 (Young, 2013), consequently it shows that the luxury market in Malaysia is expected to rise to 1.94 billion US dollars by 2018. Bian and Company (2013) subsequently updated the luxury market of Malaysia as one of the six Southeast Asian countries along with Singapore, Thailand, Indonesia, Vietnam and the Philippines, that 'drive Asian growth' for the luxury market in Asia. According to So, Parsons, and Yap (2013), the level of rivalry between luxury fashion brands is incredibly competitive in Malaysia. The 
INTERNATIONAL JOURNAL OF ACADEMIC RESEARCH IN BUSINESS AND SOCIAL SCIENCES Vol. 10, No. 10, 2020, E-ISSN: 2222-6990 @ 2020 HRMARS

overwhelming number of high-end luxury fashion houses have opened their branches in Malaysia, such as Chanel, Louis Vuitton, and Burberry. In various states of the Malaysian shopping mall, such as Starhill Gallery, The Gardens Midvalley, The Pavillion, Suria KLCC, Johor Premium Outlet, Mitsui Premium Outlet, and Genting Premium Outlet, these brands can indeed be easily accessed. On the whole, it is essential for Malaysian consumers to develop better understanding of the consumption of luxury goods, especially their initial intention of purchasing latent high end fashion items.

Similarly in Europe between 2016 and 2017, growth in luxury goods consumption stood at 6 percent, maintaining a large market share in terms of revenue and accounting for over a third of global consumption (EUR 87 billion). Additionally, France showed well throughout Deloitte 's 2017 global ranking, with three of the ten largest classes specialising in luxury goods and with LVMH in the top spot. Throughout the first nine months of the year, LVMH maintained its position as the world leader and reported a 12 percent rise in revenue, led by sales of luxury and leather products in the third quarter (Louis Vuitton, Christian Dior Couture). For other French companies, each of which reported substantial increases over the first part of the year, the year 2017 should prove to be fruitful. In the first half of 2017, the Kering Group, ranked fifth worldwide, reported practically 30 percent growth, led by the luxury market and the Gucci brand in particular, which registered impressive results in the third quarter. Evidently, through the end of September, L'Oréal Luxe also reported double-digit growth (+10.8 percent) and Hermès international (+10 percent) was ranked 12 th in terms of global revenue.

\section{Literature Review}

There are many meanings of the term luxury since every individual has different expectations and several variables, including demographics, lifestyle, habit, social climate, and, obviously, luxury surveyors and marketers, can influence the definition of luxury. According to Dubois and Laurent (1994), rapid contemplation can seemingly affect the perception of luxury. While Kapferer and Bastien (2012) believe that the definition of luxury is rather dated since it is based on humanity. Luxury is a term which means light and "lux" in Latin. Luxury implies sparkles that are somehow like a ray of sun, luxury is fascinating and beauty distinguishes. Similarly, there are couple of aspects that contribute to luxury. Firstly is the monetary capacity to pay the price of quality and the ability to enjoy the artistic, next, imaginative and alluring qualities of the product, something beyond basic expediency (Sari and Kusuma, 2014). As revealed by Vigneron and Johnson (2004), luxury products are characterised as both pleasurable and pleasant but somehow hard to acquire.

Vigneron and Johnson (1999) have thoroughly study the motive for social standards escalation influencing the consumption behavior. The five dimensions of the reasons for buying luxury goods, namely, the influence of Veblen, Snob, Bandwagon, Hedonic and Perfectionism, were also initiated by (Vigneron and Johnson, 1999). First, the Veblen effect refers to the quest for social prestige through the purchasing of high-priced goods, created by the potential to seek visible value. Accordingly, Scwartz (2004) emphasized the concept of when consumers are entitled to impress others and boost their wealth, the high price of luxury goods is given a great deal of focus and he accentuated it as the individual's hierarchical value. The hierarchical personality describes people who appear to show social superiority over others via owning luxury fashion items as they viewed to offer greater social status, (Schwartz, 2004; Wiedmann, Hennigs and Siebels, 2009). 
INTERNATIONAL JOURNAL OF ACADEMIC RESEARCH IN BUSINESS AND SOCIAL SCIENCES Vol. 10, No. 10, 2020, E-ISSN: 2222-6990 @ 2020 HRMARS

Furthermore, the second component of the Snob effect, illustrates the psychology of authenticity based on the notion of individuality. Schwartz (2004) explained that snob shoppers give greater attention to the luxury brands' distinctive status and tend to fulfil their personal desire to be different from the rest. According to Vickers and Renand (2003), the exclusivity gradually increases given the growing of price, alternatively, the higher the cost, the less accessible the brand is. On the contrary, the Bandwagon consumers depend very little on price relative to Snob customers, but assign greater priority to the social impact of prestige goods (Vickers and Renand, 2003; Wiedmann, Hennigs and Siebels, 2009). Vigneron and Johnson (1999) illustrated that for these specific consumers, the social importance of luxury brands is expressed by customer criteria for social identity. The reason for bandwagons to buy is to adhere to their desired groups and separate from their undesirable groups.

Wiedmann, Hennigs and Siebels (2009) believes that though Snobs and Bandwagons predominantly concern consumers' self-identity, their manifestations are seemingly opposite. The distinction between these two dimensions has been studied by Leibenstein (1950). He suggested that if these luxury items are bought by a mass of customers, the demand for Snobs to buy luxury goods would decrease. In contrary, if mass individuals buy the same goods, the demand for Bandwagons will grow. The social role of luxury consumption was suggested by Veblen (1899). He claimed that luxury goods are viewed as representations of social status towards others. Furthermore, the ideology of collectivism also consists of this component, suggesting the willingness to show the ability to communicate with people in social contexts by making luxury purchasing choices (Xiao \& Kim, 2009). In the same way as people prefer to equate luxury goods with prosperity and greater socioeconomic class, it is common for people sporting luxury brands to be viewed rather pompously than those wearing the ordinary brands (Nelissen and Meijers, 2011).

Alternatively. the Hedonic influence, reflecting the emotional values of consumers, is called the fourth dimension. Hedonic consumers pay little attention to the cost or the prestige metric, equivalent to the Bandwagons which stress their thoughts and emotions about luxury goods. Therefore, according to Cavender and H. Kincade, (2014) the purpose of the acquisition is to satisfy the enjoyment and excitement of customers through the tangible benefits obtained from the goods, including texture, taste, visual impression, etc. Vigneron and Johnson (1999) have clarified that hedonic impetus is more affected by customers' inner desires rather than interpersonal needs. Comparably, the dimension that ventures into the materialist explanations for the consumption of luxury goods in the study was conducted by Thomson, Maclnnis and Park (2005). The acquisition of luxury goods is considered by materialism to be the measure of well-being, satisfaction and life's progress particularly extracted from the individual understanding of luxury products.

Lastly, the final dimension that centers around the quality value of high-end brands known as the Perfectionism effect. The emphasis in this dimension is on the product itself, primarily on consistency. This dimension was described by Wong and Ahuvia (1998) as the integrative motivation associated with quality of endogenous luxury. According to Husic and Cicic (2009), perfectionist customers are more in compliance with their understanding of the practicality and durability of the commodity and prefer to focus on price as a guide for decision. Generally, three scopes can be divided into the above five dimensions. In terms of the quality value of luxury brands, the first scope includes the luxury product itself, such as the Perfectionism effect. Secondly, the scope concerns the psychology and 
personal desire for luxury goods, which consists of the Hedonic effect in terms of consumer subjective standards and the Snob effect of distinction psychology. Lastly, the final scope deals with the sociocultural roles of luxury consumption, known as the Bandwagon effects, which are the social implications of prestige goods, and the impact of the Veblen, which focused on the quest for social prestige.

\section{Methodology}

Furthermore, due to the focus of the research on the variables affecting the consumption of personal luxury brands in Malaysia, the population for this study centers around those consumers who bought personal luxury brands in Malaysia. Evidently, 142 customers will be the experimental sample. According to Guadgnoli and Velicer (1988) the recommendation for a minimum size of 100 to 200 sample size for observations is possibly based on the claim that when sample sizes exceed this amount, the correlation coefficient has become an accurate estimator of the population correlation coefficient. The research was conducted primarily in Kuala Lumpur, Malaysia also known as Malaysia's capital city. Moreover, majority of the brands are accessible in Kuala Lumpur. Besides, the author distributed self-administered questionnaires to be completed by the respondents in order to retrieve the data. This kind of questionnaire is distributed to respondents by hand. Specifically, It is easier to administer such questionnaires, comparatively cheaper than face-to-face surveys, and it also allows a large number of people to be part of the process (Saunders and Bezzina, 2015). Accordingly, the questionnaire has been adapted and is separated into eight main parts for this analysis. To prove each hypothesis, the rest of the seven parts were geared at gathering the data. Subsequently, the 5-point Likert scale was used in this study.

\section{Findings}

Using SPSS, the data was analysed and the final statistical analysis report was presented in the following section. Throughout this study, forms of analysis have been used starting with the frequency analysis and followed descriptive analysis.

\section{Frequency Analysis}

For this research, frequency analysis was the fundamental approach where it was precisely analyzed. The profile of the respondents are listed in more detail in this section. Data was gathered in the questionnaire from Section $\mathrm{F}$, which comprised of multiple kinds of demographic inquiries such as gender, age, ethnicity, qualification, income, purchase frequency and consumption of favorable personal luxury brands. On the whole, the study presented the demographic findings of respondents into table forms. 
INTERNATIONAL JOURNAL OF ACADEMIC RESEARCH IN BUSINESS AND SOCIAL SCIENCES

Vol. 10, No. 10, 2020, E-ISSN: 2222-6990 @ 2020 HRMARS

Table 1: Number of Respondent by Gender in Kuala Lumpur

Demographic Frequency Percentage (\%)

\begin{tabular}{llll}
\hline Sex: & Male & 36 & $\mathbf{2 5 . 4}$ \\
& Female & 106 & 74.6 \\
Total & $\mathbf{1 4 2}$ & $\mathbf{1 0 0}$
\end{tabular}

Table 2: Number of Respondent by Gender in Paris

Demographic Frequency Percentage (\%)

\begin{tabular}{llll}
\hline Sex: & Male & 51 & 35.9 \\
& Female & 91 & 64.1 \\
& Total & $\mathbf{1 4 2}$ & $\mathbf{1 0 0}$
\end{tabular}

"Respondent by Gender" in Kuala Lumpur and Paris are seen on the basis of Table 1 and Table 2. The majority of respondents in Kuala Lumpur and Paris were women extending to 74.6 percent, and 64.1 percent, based on the number of questionnaires distributed in both countries, comprising 284 respondents.

Table 3: Number of Respondent by Age in Kuala Lumpur

Demographic Frequency Percentage (\%)

\begin{tabular}{llll} 
Age: & 18 to 24 & 24 & 16.9 \\
25 to 34 & 44 & 31.0 \\
35 to 44 & 43 & 50.3 \\
45 to 54 & 23 & 16.2 \\
55 or older & 8 & 5.6 \\
& Total & $\mathbf{1 4 2}$ & $\mathbf{1 0 0 . 0}$ \\
\hline
\end{tabular}

Table 4: Number of Respondent by Age in Paris

Demographic Frequency Percentage (\%)

\begin{tabular}{llll} 
Age: & 18 to 24 & 70 & 49.3 \\
25 to 34 & 32 & 22.5 \\
35 to 44 & 24 & 16.9 \\
45 to 54 & 15 & 10.6 \\
& 55 or older & 1 & 0.7 \\
& Total & $\mathbf{1 4 2}$ & $\mathbf{1 0 0 . 0}$ \\
\hline
\end{tabular}

Next, the number of respondents by age in Kuala Lumpur and Paris is presented in Table 3 and Table 4. In Kuala Lumpur, the majority of respondents are 35 to 44 years old, with a percentage of 50.3 
INTERNATIONAL JOURNAL OF ACADEMIC RESEARCH IN BUSINESS AND SOCIAL SCIENCES

Vol. 10, No. 10, 2020, E-ISSN: 2222-6990 @ 2020 HRMARS

percent, followed by 25 to 34 years old, then 18 to 24 years old, followed by 45 to 54 years old. Subsequently, 5.6 percent of respondents aged between 55 and over are in the remaining balance. While in Paris, the majority of respondents were 18 to 24 years old with a percentage of 49.3\%, followed by 25 to 34 years old, then 35 to 44 years old and followed by the estimates of 45 to 54 years old. The remaining balance is $0.7 \%$ of respondents aged between 55 and over.

Table 5: Number of Respondent by Ethnicity in Kuala Lumpur

Demographic Frequency Percentage (\%)

\begin{tabular}{llll}
\hline Race: & Asian/Pacific Islander & 4 & 2.8 \\
& Arab & 5 & 3.5 \\
Malay & 109 & 76.8 \\
Chinese & 13 & 9.2 \\
Indian & 10 & 7.0 \\
Others & 1 & 0.7 \\
Total & $\mathbf{1 4 2}$ & $\mathbf{1 0 0 . 0}$
\end{tabular}

Table 6: Number of Respondent by Ethnicity in Paris

Demographic Frequency Percentage (\%)

\begin{tabular}{llll}
\hline Race: & Black/African American & 8 & 5.6 \\
& White/Caucasian & 114 & 80.3 \\
Arab & 17 & 12.0 \\
Malay & 1 & 0.7 \\
Others & 2 & 1.4 \\
Total & 142 & $\mathbf{1 0 0 . 0}$ \\
\hline
\end{tabular}

Moreover, Table 5 and Table 6 show the number of respondents by ethnicity in Kuala Lumpur and Paris. Majority of the respondents in Kuala Lumpur were Malays at $76.8 \%$, followed by Chinese at 9.2\%, and India at 7.0\%. Furthermore, followed by Arabic at 3.5\%, Asian/Pacific Islander 2.8\% The remaining balance was $0.7 \%$. Meanwhile in Paris, the majority of respondents were White/Caucasian at $80.3 \%$, followed by Arabs by $12.0 \%$, and Black/African at $5.6 \%$. The remaining $1.4 \%$ of the remaining balances were Malays at $0.7 \%$. 
INTERNATIONAL JOURNAL OF ACADEMIC RESEARCH IN BUSINESS AND SOCIAL SCIENCES

Vol. 10, No. 10, 2020, E-ISSN: 2222-6990 @ 2020 HRMARS

\section{Table 7: Number of Respondent by Qualification in Kuala Lumpur}

\section{Demographic Frequency Percentage (\%)}

\begin{tabular}{llll}
\hline Qualification: & Less than a high school diploma & 6 & 4.2 \\
& High school degree/equivalent & 8 & 5.6 \\
& Some college, no degree & 9 & 6.3 \\
Associate degree & 8 & 5.6 \\
Bachelor's degree & 70 & 49.3 \\
Master's degree & 27 & 19.0 \\
Professional degree & 5 & 3.5 \\
Doctorate & 5 & 3.5 \\
Others & 4 & 2.8 \\
Total & $\mathbf{1 4 2}$ & $\mathbf{1 0 0 . 0}$ \\
\hline
\end{tabular}

Table 8: Number of Respondent by Qualification in Paris

Demographic Frequency Percentage (\%)

\begin{tabular}{llll}
\hline Qualification: & High school degree/equivalent & 33 & 23.2 \\
& Some college, no degree & 5 & 3.5 \\
& Associate degree & 2 & 1.4 \\
Bachelor's degree & 45 & 31.7 \\
Master's degree & 44 & 31.0 \\
Professional degree & 12 & 8.5 \\
Others & 1 & 0.7 \\
Total & $\mathbf{1 4 2}$ & $\mathbf{1 0 0 . 0}$
\end{tabular}

Furthermore, Table 7 and Table 8 shows the number of respondents by level of education in Kuala Lumpur and Paris. Majority of the respondents in Kuala Lumpur had a bachelor's degree of $49.3 \%$, followed by Master's degree of $19.0 \%$. Respondents with professional degrees and Doctorate had the same percentage of 3.5\%. Meanwhile in Paris, the majority of respondents had at least a bachelor's degree representing a percentage of 31.7\%, followed by Master's degree of $31.0 \%$ and high school degree equivalent of $23.2 \%$. For Kuala Lumpur and Paris, the respondents who chose others represented the lowest percentage in both countries at $2.8 \%$ in Kuala Lumpur and only $0.7 \%$ in Paris. 
INTERNATIONAL JOURNAL OF ACADEMIC RESEARCH IN BUSINESS AND SOCIAL SCIENCES

Vol. 10, No. 10, 2020, E-ISSN: 2222-6990 @ 2020 HRMARS

\section{Table 9: Number of Respondent by Employment in Kuala Lumpur}

Demographic Frequency Percentage (\%)

\begin{tabular}{llll}
\hline Employment: & Full-time employment & 100 & 70.4 \\
& Part-time employment & 5 & 3.5 \\
& Unemployed & 4 & 2.8 \\
& Self-employed & 12 & 8.5 \\
& Student & 16 & 11.3 \\
Retired & 4 & 2.8 \\
Others & 1 & 0.7 \\
Total & $\mathbf{1 4 2}$ & $\mathbf{1 0 0 . 0 0}$ \\
\hline
\end{tabular}

Table 10: Number of Respondent by Employment in Paris

\section{Demographic Frequency Percentage (\%)}

\begin{tabular}{llll}
\hline Employment: & Full-time employment & 61 & 43.0 \\
& Unemployed & 2 & 1.4 \\
& Self-employed & 8 & 5.6 \\
& Student & 68 & 47.9 \\
& Retired & 3 & 2.1 \\
& Total & $\mathbf{1 4 2}$ & $\mathbf{1 0 0 . 0}$
\end{tabular}

Table 9 and Table 10 show the number of employment status in Kuala Lumpur and Paris. Majority of the respondents in Kuala Lumpur at $70.4 \%$ were full-time employment followed by students at $11.3 \%$, and $8.5 \%$ of respondents were self-employed. Next, $3.5 \%$ of the respondents were part-time employment, and the unemployed and retired respondents had the same percentage of $2.8 \%$. Meanwhile, $0.7 \%$ of respondents chose others. Respondents in Paris showed that $47.9 \%$ of respondents were students, while $43.0 \%$ of respondents in Paris were full-time employment, followed by $5.6 \%$ of respondents were self-employed. Next, $2.1 \%$ of the respondents in Paris were retired and the remaining $1.4 \%$ were unemployed. 
INTERNATIONAL JOURNAL OF ACADEMIC RESEARCH IN BUSINESS AND SOCIAL SCIENCES

Vol. 10, No. 10, 2020, E-ISSN: 2222-6990 @ 2020 HRMARS

Table 11: Number of Respondent by income in Kuala Lumpur

Demographic Frequency Percentage (\%)

\begin{tabular}{llll}
\hline Income: & RM 0 - RM 20,000 & 82 & 57.7 \\
RM 20,001 - RM 40,000 & 28 & 19.7 \\
RM 40,001 - RM 60,000 & 11 & 7.7 \\
RM 60,001 - RM 80,000 & 12 & 8.5 \\
RM 80,001 - RM 100,000 & 7 & 4.9 \\
RM 100,001 - above & 2 & 1.4 \\
Total & 142 & $\mathbf{1 0 0 . 0}$
\end{tabular}

Table 12: Number of Respondent by income in Paris

Demographic Frequency Percentage (\%)

\begin{tabular}{llll}
\hline Income: & Euro 0 - Euro 20,000 & 75 & 52.8 \\
& Euro 20,001 - Euro 40,000 & 7 & 4.9 \\
Euro 40,001 - Euro 60,000 & 35 & 24.6 \\
Euro 60,001 - Euro 80,000 & 24 & 16.9 \\
Euro 80,001 - Euro 100,000 & 1 & 0.7 \\
Total & 142 & $\mathbf{1 0 0 . 0}$
\end{tabular}

Furthermore, Table 11 and Table 12 show the Number of Respondent by income in Kuala Lumpur and Paris. Majority of the population in Kuala Lumpur achieve an income between RM 0 - RM 20,000 which was $57.7 \%$. The findings were similar to those in Paris at $52.8 \%$ of respondents with income between Euro 0 - Euro 20,000. In Kuala Lumpur, only 1.4\% of respondents had income between RM 100,001 and above. While in Paris, only $0.7 \%$ of respondents had income of Euro 80,001 to Euro 100,000 . There are no respondents in Paris who own earnings of between Euro 100,001 and above.

Table 13: Number of Respondent by Purchase frequency in Kuala Lumpur

Demographic Frequency Percentage (\%)

\begin{tabular}{llll}
\hline Purchase frequency: & Monthly & 11 & 7.7 \\
& Once a year & 58 & 40.8 \\
& Twice a year & 39 & 27.5 \\
& Others & 34 & 23.9 \\
& Total & 142 & 100.0 \\
\hline
\end{tabular}


INTERNATIONAL JOURNAL OF ACADEMIC RESEARCH IN BUSINESS AND SOCIAL SCIENCES Vol. 10, No. 10, 2020, E-ISSN: 2222-6990 @ 2020 HRMARS

Table 14: Number of Respondent by Purchase frequency in Paris

Demographic Frequency Percentage (\%)

\begin{tabular}{llll}
\hline Purchase frequency: & Weekly & 3 & 2.1 \\
& Monthly & 13 & 9.2 \\
& Once a year & 31 & 21.8 \\
& Twice a year & 19 & 13.4 \\
Other & $\mathbf{7 6}$ & 53.5 \\
Total & $\mathbf{1 4 2}$ & $\mathbf{1 0 0}$ \\
\hline
\end{tabular}

Table 13 and Table 14 show Number of Respondent by Purchase frequency in Kuala Lumpur and Paris. In Kuala Lumpur, a majority of $40.8 \%$ of the total respondents chose to purchase luxury goods at least once a year followed by once in two years at $27.5 \%$. While in Paris, most of the respondents chose another $53.5 \%$ which is that the respondents made a weekly purchase, followed by only once a year at $13.4 \%$. In Paris. branded goods are more frequently purchased as they are relatively cheaper than in Kuala Lumpur. 
INTERNATIONAL JOURNAL OF ACADEMIC RESEARCH IN BUSINESS AND SOCIAL SCIENCES Vol. 10, No. 10, 2020, E-ISSN: 2222-6990 @ 2020 HRMARS

Table 15: Number of Respondent by Preferred luxury brands in Kuala Lumpur

Demographic Frequency Percentage (\%)

\begin{tabular}{clll}
\hline Preferred luxury brands: & Montblanc & 15 & 10.6 \\
& Tissot & 19 & 13.4 \\
Tod's & 5 & 3.5 \\
Prada & 23 & 16.2 \\
Gucci & 15 & 10.6 \\
Luois Vuitton & 12 & 8.5 \\
Tiffany \& Co & 9 & 6.3 \\
Berluti & 1 & 0.7 \\
Tag Huer & 1 & 0.7 \\
Rolex & 2 & 1.4 \\
Omega & 3 & 2.1 \\
Cartier & 3 & 2.1 \\
Chopard & 3 & 2.1 \\
Bulgari & 7 & 4.9 \\
Hermes & 4 & 2.8 \\
IWC & 1 & 0.7 \\
Bottega Veneta & 1 & 0.7 \\
Patek Philippe & 3 & 2.1 \\
Harry Winston & 1 & 0.7 \\
Others & 14 & 9.9 \\
Total & 142 & 100.0 \\
\hline
\end{tabular}


INTERNATIONAL JOURNAL OF ACADEMIC RESEARCH IN BUSINESS AND SOCIAL SCIENCES

Vol. 10, No. 10, 2020, E-ISSN: 2222-6990 @ 2020 HRMARS

Table 16: Number of Respondent by Preferred luxury brands in Paris

\section{Demographic Frequency Percentage (\%)}

\begin{tabular}{llll}
\hline Preferred luxury brands: & Montblanc & 8 & 5.6 \\
& Tissot & 7 & 4.9 \\
Prada & 5 & 3.5 \\
Gucci & 10 & 7.0 \\
Louis Vuitton & 12 & 8.5 \\
Tiffany \& Co & 3 & 2.1 \\
Tag Huer & 2 & 1.4 \\
Rolex & 6 & 4.2 \\
Omega & 1 & 0.7 \\
Cartier & 2 & 1.4 \\
Hermes & 5 & 3.5 \\
Patek Philippe & 2 & 1.4 \\
Breguet & 1 & 0.7 \\
Harry Winston & 2 & 1.4 \\
Others & 76 & 53.5 \\
Total & 142 & 100.0 \\
\hline
\end{tabular}

Lastly, Table 15 and 16 show Number of Respondent by Preferred luxury brands in Kuala Lumpur and Paris. Top 3 brands which were the choice of respondents in Kuala Lumpur were Prada at 16.2\%, followed by Tissot at $13.4 \%$. While the Montblanc and Gucci brands share the same position, as $10.6 \%$ of respondents share the same interest for both brands. Different findings come when looking at the top 3 brand tendencies of choice of respondents in Paris. Majority of respondents in Paris chose Others at $53.5 \%$. Most respondents have listed other brands such as Givenchy, Balenciaga and Miu Miu as preferred brands. Followed by Louis Vuitton at $8.5 \%$ and Montblanc at $5.6 \%$. The Montblanc brand is the top 3 brands that seem to be the choice of respondents for both countries.

\section{Conclusion and Recommendation}

This research stimulate two crucial points concerning the field of luxury merchandising literature by dedicating to two important points. First, by comparing Kuala Lumpur, Malaysia, and Paris, France, the analysis describes the disparities between Western and Asian cultures. This is the first study documented by this researcher that contrasted luxury brand intentions with those two particular cultures. In several previous research studies by Bian \& Forsythe (2012); Hennigs et al (2012) Park, Ko, \& Kim(2010); Shukla (2011); Shukla and Purani (2012), have initiated the contrasting elements of luxury brands consumptions between the western society and the eastern Asian cultures. Eventually, this research centres only on the participants from Kuala Lumpur and Paris as the intended sample. Thus, the total population in Malaysia and France were not adequately represented. In order to achieve comprehensive results, more studies should take into account the inclusion of more towns. 
INTERNATIONAL JOURNAL OF ACADEMIC RESEARCH IN BUSINESS AND SOCIAL SCIENCES Vol. 10, No. 10, 2020, E-ISSN: 2222-6990 @ 2020 HRMARS

Nonetheless, some strategic implications for luxury brand retailers in both the Kuala Lumpur and Paris markets were generated by the results of this research. Fashion brands like Prada, Tissot. Montblanc and Gucci were the top personal luxury brands favoured by Kuala Lumpur buyers, whereas, Others (Givenchy, Balenciaga, Miu Miu), Louis Vuitton and Montblanc were the top personal luxury brands favoured by Paris customers. Subsequently, marketers of these top personal luxury brands should therefore continue the great promotional advertising of their brand hence retain their success. Accordingly, other luxury brands will hopefully learn and able to determine the explanations behind higher aspirations for these brands from the leading brands recognized by customers in this research.

This paper establishes the significant differences on the consumer buying behaviours, decision processes and brand preferences between Kuala Lumpur and Paris. In the light of this research, the researcher hopes that it may benefit the body of knowledge in the area of personal luxury brand consumption and consumers purchasing behaviours. Furthermore, in investing on personal luxury brand, the consumers and marketers should develop a great understanding on the purchasing factors that influence purchasing decisions, the variables that impact consumer purchases and the evolving dynamics surrounding the culture. The research has illustrate numerous variables that have been analysed suggesting that gender, age, ethnicity, education level of respondents, occupation, level of income of individuals purchase frequency and preferred luxury brand may affect the consumption of personal luxury brands. Hence, the research conducted may contributes to the establishment of knowledge that is indispensable to the diligence of luxury brand consumption and also served as a platform for exploring the immense potential exhibit through in-depth analysis, especially crosscountry comparisons.

\section{References}

Bain \& Company. (2014). Bain and Company's 2014 annual global luxury study proclaims the rise of the consumer as luxury markets settle in for lower, but more sustainable long-term growth. [Online] Available at: http://www.bain.com/about/press/press- releases/bain-andcompanys-2014-annual-global-luxury-study.aspx. [Accessed 11 June 2020].

Cavender, R., \& Kincade, H. D. (2014). Management of a luxury brand: dimensions and sub-variables from a case study of LVMH. Journal of Fashion Marketing and Management: An International Journal, 18(2), pp.231-248.

Chandran, N. (2014). Forget China, this is the next big luxury market. The CNBC news. Retrieved 3 August 2020 from https://www.cnbc.com/2014/09/24/forget-china-thisis-asias-new-luxury-market.html

Dubois, B., \& Laurent, G. (1994) Attitudes toward the concept of luxury: An exploratory analysis. AsiaPacific Advances in Consumer Research 1(2), 273-278.

Euromonitor International. (2016). Luxury goods in Malaysia. Retrieved 3 August 2020 from http://www.euromonitor.com/luxury-goods-in-malaysia/report

Guadagnoli, E., \& Velicer, W. F. (1988). Relation of sample size to the stability of component patterns. Psychological Bulletin, 103(2), 265- ～275. https://doi.org/10.1037/00332909.103.2.265

Husic, M., \& Cicic, M. (2009). Luxury Consumption Factors. Journal of Fashion Marketing and Management, (13/2), 231-243. 
INTERNATIONAL JOURNAL OF ACADEMIC RESEARCH IN BUSINESS AND SOCIAL SCIENCES

Vol. 10 , No. 10, 2020, E-ISSN: 2222-6990 @ 2020 HRMARS

Kapferer, J. N., \& Bastien, V. (2012). The Luxury Strategy: Break the Rules of Marketing to Build Luxury Brands (2nd Edition). London, UK: Kogan Page.

Leibenstein, H. (1950). Bandwagon, snob ve veblen effects in the theory of consumers' demand. Quarterly Journal Of Economics, 64, 183-207.

Nelissen, R. M., \& Meijers, M. H. (2011). Social benefits of luxury brands as costly signals of wealth and status. Evolution and Human Behavior, 32(5), 343-355.

Young, R. (2013). Malaysia revels in spending power. The New York Times. Retrieved 3 August 2020 from http://www.nytimes.com/2013/11/22/fashion/Malaysia-Revels-in-SpendingPower.html

Saunders, M. N. K., \& Bezzina, F. (2015). Reflections on conceptions of research methodology among management academics. European Management Journal. Vol. 33, no. 5, pp. 297. https://doi.org/10.1016/j.emj.2015.06.002.

Sari, D., \& Kusuma, B. (2014). Does Luxury Brand Perception Matter In Purchase Intention? A Comparison Between A Japanese Brand And A German Brand. Asean Marketing Journal.

So, T. J., Parsons, G. A., \& Yap, S. F. (2013). Corporate branding, emotional attachment, and brand loyalty: the case of luxury fashion branding. Journal of Fashion Marketing and Management: An International Journal, 17(4), 403- 423.

Thomson, M., Maclnnis, D. J., \& Park, C. W. (2005). The ties that bind: Measuring the strength of consumers' emotional attachments to brands. Journal of consumer psychology, 15(1), 7791.

Veblen, T. (1899). The theory of the leisure class. Pennsylvania, Penn: A Penn State Electronic Classics Series Publication.

Vigneron, F. \& Johnson, L.W. (1999) 'A review and a conceptual framework of prestige-seeking consumer behavior' Academy of Marketing Science Review [Online]. 99 (1): 1-15.

Vigneron, F., \& Johnson, L. W. (2004) Measuring perceptions of brand luxury. Journal of Brand Management 11(6), 484-508.

Wiedmann, K.P., Hennigs, N., \& Siebels, A. (2007). Measuring Consumers' Luxury Value Perception: A Cross-Cultural Framework. Academy of Marketing Science Review 11, 1-21.

Wong, N. Y., \& Ahuvia, A. C. (1998) Personal taste and family face: Luxury consumption in Confucian and Western societies. Psychology \& Marketing 15(5), 423-441. 